\title{
On the Dominant Status of American Educational Market for Foreign Students Since 1980s
}

\author{
Jun Shu \\ English Department, Zhenjiang Watercraft College \\ Box No. 130 Taohuawu Road, Zhenjiang, Jiangsu Province, 212003, China \\ Tel: 86-511-8533-9633Ｅ-mail: shujun97@yahoo.com.cn
}

Received: August 7, 2011 Accepted: August 24, $2011 \quad$ Published: February 1, 2012

doi:10.5539/ies.v5n1p147 URL: http://dx.doi.org/10.5539/ies.v5n1p147

\begin{abstract}
The article first probes into some reasons for the formation and the rise of the world educational market for foreign students. Then the article focuses on several important ensuring the absolutely dominant status of the U.S. educational market for foreign students in the world since 1980s and finally concludes that it is the U.S. world-leading comprehensive national strength that has firmly established its dominating position in the world educational market for foreign students in recent decades.
\end{abstract}

Keywords: American educational market, Foreign students, Dominant status

\section{Introduction}

\subsection{Definition of Foreign Students in the Paper}

First of all, it is essential to define the term "foreign students" discussed in this research paper. Foreign students are specifically referred to those internationally mobile students at least at university-level who pursue cultural education and skill training on a short-term basis from one nation to another, who are also known as international students.

\subsection{Rise of World Educational Market for Foreign Students}

The first round of upsurge of the world education for foreign students in the 20th century emerged soon after the end of the Second World War. From early 1950s to the end of the 1970s, the most advanced nations in the world such as the U.S., the U.K., France, etc. actively promoted the education for foreign students mainly out of their political, educational and cultural considerations. With the growing relaxation of the world tensions and due to the trend toward the internationalization of world economy and trade, the world education for foreign students since the 1980s has achieved remarkable process in the following two aspects.

(1) There has been a considerable increase in the total number of international students worldwide. In 1980, the number of foreign students worldwide attained more than 900, 000 while in 1990 and in 1995 the figure amounted to $1,200,000$ and $1,600,000$ respectively;

(2) Since the 1980s, besides political, educational and cultural benefits, developed nations have laid unprecedented emphasis on the pursuit of economic benefits through the education for foreign students. Taking into account the growing number of foreign students worldwide and the enormous economic interests available from the education for foreign students, the United Kingdom took the world lead in advancing the concept of "the educational market for foreign students in the world" at the end of 1970s and the early 1980s.

\subsection{Main Causes for the Formation of the World Educational Market for Foreign Students}

\subsubsection{Scarcity of Higher Educational Funds in the Developed Nations}

At the end of the 1970s, most developed countries in the world faced difficult economic conditions. Governments in those nations had to adjust public policies and cut down the investment into the educational field to get rid of financial difficulties. Accordingly, the higher education institutions in those countries had to expand channels for fund-raising so as to solve diversified problems caused by the reduction in education investment by the government. One of the most effective measures was to increase the tuition cost paid by students. In general, the tuition paid by foreign students was higher than that paid by native ones. As a result, the developed nations looked forward to recruiting more foreign students to study in their countries to make up for the scarcity of higher educational funds. 
1.3.2 Contradiction between the Rapid Expansion of the Scope of Higher Education and Scarcity of Native Student Populations of the Right Age for Receiving Higher Education in Developed Nations

Since the 1950s, the scope of higher education in the developed nations has been expanding at a surprising rate with the ever-growing influence of the democratization of higher education. In 1960, the average attendance ratio in the colleges and universities in the advanced countries achieved 12.8 percent while in 1970 and 1975, the figure rose to 23.4 and 28.3 percent respectively. In the early 1980 s, most developed nations achieved the popularization of higher education with the attendance ratio exceeding 30 percent. On the one hand, the developed nations possessed ample capacities for receiving numerous students; on the other hand, the number of native student populations of the right age for receiving higher education in the developed countries was on a constant decrease in the early 1980s. In order to solve this contradiction, the developed nations had to further recruit more foreign students.

\subsubsection{Change in the World Situation}

Entering into the 1980s, peace and development have become the main theme of the times. In order to consolidate world peace and development, the exchange and understanding between different cultures in the world are essential and at the same time the high-level international talents who excel at world economic rules or advanced science and technology are badly needed so as to win the rapid economic development. Studying abroad has been undoubtedly the most effective and simplest way to achieve the above-mentioned goals. As a result, both developed and developing countries have been encouraging their students to study abroad, thus creating an international environment favorable for the formation of the educational market for foreign students worldwide.

\section{The U.S Has Been Dominating the World Educational Market for Foreign Students Since 1980s}

Since the 1980s, the influence of the United States has been increasing in almost every respect. In the field of higher education, for instance, the U.S. has successfully maintained a globally dominant status in the educational market for foreign students in the world in the fact that it has been holding the highest number of foreign students worldwide which can be clearly shown in Table 1 .

\section{Various Factors Resulting in the US Dominant Status in the World Educational Market for Foreign Students}

In fact, the American educational market for foreign students dominating the world since the 1980s is largely due to quite a number of objective and subjective factors. The objective factors have mainly been derived from its higher education, science, technology, economy and even the unique American culture. Deliberate efforts made by the whole U.S. society can be viewed as subjective factor. In addition, drastic political and economic changes in the world have also to some extent contributed to the dominant status of the American educational market for foreign students in the world.

\subsection{American Higher Education}

The U.S. has maintained the status of being the most attractive nation for foreign students in the world since the 1980s. The largest attraction has been undoubtedly derived from three outstanding charms of American higher education.

\subsubsection{Academic Excellence}

Since the 1980s, the popular study fields chosen by foreign students coming to the U.S. have been business and management, engineering, mathematics and computer science. Most foreign students at graduate-level preferred to choose engineering and natural science as their most popular study fields while most undergraduate students selected business and management. Foreign students' choices on their popular study fields at the U.S. colleges and universities indicate that foreign students, for one thing, expect to acquire pragmatic academic degrees which will ensure their economic gains in the future; for another, they have been attracted to a large extent by the academic excellence of the American higher education as it is well-known that American business practices, science and technology have been world-class and in many fields have been the dominant international standard establishers since the 1980s.

The quality of the American higher education has been really enjoying the highest international reputation since the 1980s. An evaluation made in 1992 by the Geneva-based International Teachers' Association claimed that the U.S. owned six of the top 10 best universities in the world. The U.S. colleges and universities have also been universally acknowledged to be the most competitive in the field of scientific research. Among the top 20 universities that achieved the greatest scientific research achievements in the world in 1992, the U.S. alone held 16.

\subsubsection{Two Features of American Higher Education}

(1) Diversification 
Diversification can be considered as one of the most important features of the American higher education. The U.S. colleges and universities can be roughly divided into four categories: (a) the university, (b) the four-year undergraduate institution (c) The technical training institution, and (d) the two-year college, or community college.

Many other countries may also have had these four kinds of institutions of higher learning, but the American higher education has been larger in scope and more diverse than anywhere else in the world. The diversification of the American higher education has enabled foreign students to choose institutions of higher learning according to their study objectives and specific requirements. In a word, the diversified higher educational system in the U.S has provided foreign students with a variety of educational opportunities.

\section{(2) Openness}

The American higher educational system has been universally acknowledged to be the most open one in the world. Foreign students with different cultures have been traditionally welcome by the American colleges and universities, regardless of their ages, races or places of origins. As a result, the U.S. native students tend to deal with their foreign counterparts in a relatively friendly way under the influence of the open atmosphere of the American higher education and therefore, foreign students in the U.S. campuses have felt comparatively less exclusive in their deep hearts.

\subsubsection{More Opportunities for Undertaking Scientific Research}

In general, foreign students at graduate level in the U.S. colleges and universities have had more opportunities to be engaged in the scientific research. For one thing, the U.S. colleges and universities have attached much importance to scientific research and frequently carried out large-scale research experiments that required numerous scientific personnel; for another, foreign students at graduate level have been traditionally valued high by the American higher education in the field of scientific research in the belief that foreign students can bring fresh professional skills and creative ideas to the laboratories. As a result, more opportunities for undertaking scientific research in the U.S. campuses have produced much fascination in the minds of foreign students.

\subsection{The Highly Developed American Science and Technology}

\subsubsection{Brief Review of the Development of the World Education for Foreign Students}

The world education for foreign students in the modern time originated in the United Kingdom in the late $18^{\text {th }}$ century when the U.K. was dominating the world in the field of science and technology due to its invention and wide use of steam engines, the highest technological achievement at that time. Thousands of foreign students worldwide flew into the U.K. to study the most advanced science and technology then. Between the middle $19^{\text {th }}$ century and the early $20^{\text {th }}$ century, the technological revolution in the chemical industry first took place in Germany, which turned Germany to be the new scientific and technological center in the world and the flow of foreign students worldwide began to shift from the U.K. to Germany. From the early $20^{\text {th }}$ century to the end of the Second World War, the U.S. scientific and technological strength was greatly improved. Since the end of the Second World War, the U.S. became the new leader in the world science and technology and it gradually turned out to be the most attractive nation for foreign students ever since. The brief review of the development of the world education for foreign students reveals in a clear way that a nation's scientific and technological strength in the world plays a critical role in attracting foreign students to the nation. Similarly, the U.S. has been the most attractive nation for foreign students from around the world since the 1980s because it has maintained its top scientific and technological strength in the world.

\subsubsection{U.S. Scientific and Technological Factors}

(1) U.S. has been holding the various technological talents with the largest quantity and the best quality in the world since the $1980 \mathrm{~s}$

In terms of the quantity of the technological talents, the U.S. possessed 2.54 million scientists and engineers in 1993 while Japan, ranked second in the number of technological talents in the world, owned only 984 thousand in the same year. In addition, the quality of the U.S. technological talents has also been top in the world since the 1980s. For example, between 1990 and 1999, altogether 35 Americans have won the honorable Nobel Prize for natural science, representing nearly two-thirds of the world total. In 1995 alone, among nine Nobel-Prize winners seven were Americans.

(2) U.S. Scientific and Technological Strength in the World since the 1980s Can Be Shown from its quantity of Scientific Research Papers Published in the World Major Scholarly Journals.

Since the 1980s, the American scientific research papers have normally accounted for more than one-third of the world total. In 1990, all together 357,750 pieces of American research papers were collected by the world 
acknowledged four major searching systems of scientific and technological literature known as SCI, ISTP, ISR and EI, representing more than 35 percent of the world total while the U.K. and Japan holding 8.16 and 7.2 percent respectively.

(3) The U.S. has led a safe lead in numerous high-technological fields, such as information, communication, biological engineering, new material and new energy since the 1980s.

In March 1995, the White House published a report entitled On The National Critical Technologies and it claimed that almost all American critical technologies were either superior to or at the same level with those of Japan and the Western European countries.

\subsection{U.S Economic Factors Concerned with its Higher Education}

Just as the U.S. top scientific and technological strength in the world has played a critical role in attracting the largest number of foreign students worldwide since the 1980s, American economic power has surely played a fundamental part. For one thing, the higher living standard in the U.S. has been highly inviting to foreign students, especially to those from the developing countries, for another, the academic excellence of the American higher education and the world-leading status of the U.S. science and technology are heavily dependent on the world largest investment in the fields of higher education, science and technology.

In the first place, the academic excellence of the American higher education has been much relied upon the world largest economic investment. Since the 1980s, the U.S. has topped the world in the amount of annual higher educational funds accounting for nearly 40 percent of the world total.

In the second place, the U.S. has also served as the world-biggest investor in the field of scientific research and development since the $1980 \mathrm{~s}$ in order to maintain its globally dominant status of scientific and technological strength. An internationally comparative study on the funds of scientific research and development by the most developed nations is indicated in table 2 .

\subsection{American Culture}

The development of the world education for foreign students has also shown that besides the attraction of a nation's scientific and technological strength in the world, foreign students also prefer to flow into a host country that has strong historical, linguistic and cultural ties with their native countries. For example, France has hosted the majority of French-speaking students from Africa. Sizeable numbers of students from Algeria, the Congo, Morocco, Senegal, Tunisia, and the United Republic of Cameroon attended French universities; the U.K. has also received numerous students from British Commonwealth. These facts doubtlessly show that a country's culture also plays a role in attracting foreign students to the nation to some extent. In general, the attractive forces of the American culture in drawing foreign students have mainly been deprived from the following two aspects.

\subsubsection{The English Language}

English, the American native language, has doubtlessly played a certain role in drawing the highest number of foreign students worldwide since the 1980s. In the first place, English has become more popular than any other international language in the world, such as French, German and Russian. Since the 1980s, English has been spoken not only in such countries as the United Kingdom, the United States, Australia, New Zealand where English is their native language but also has been officially used in nearly one hundred countries and regions around the world. Even if in some countries where English has not been the official language, people can still communicate in English there. A British article once described the increasing popularity of English as follows: "English is known as an increasingly popular world language. It is estimated that the total number of English-speaking natives is about 300 to 400 million. About 1600 million people live in countries where English has been recognized as the official second language". In the second place, English, particularly the American English has been increasingly important as it has won absolute superiority over any other international language of scholarship due to the globally dominant status of the U.S. science, technology and economy. It has been reported that the bulk of the world's scientific and technological literature now appears in English. Even scholars in other advanced nations where English is not spoken as the native language have often found it absolutely necessary to communicate their scientific findings in English. The fact that foreign students in other major countries where English is not the language of instruction had to learn English was also favorable for the American higher education because the U.S. has had more capacity to provide higher education studies in English than any other country in the world. Indeed, the U.S. had about three times the capacity as that of the other four major English-speaking countries taken together. (Note 1)

\subsubsection{American Cultural Characteristics}

Besides the American linguistic superiority, the characteristics of American culture have also been highly attractive 
to foreign students since the 1980s. In general, the principal characteristics of the American culture in the $20^{\text {th }}$ century have been openness, pluralism, and pervasiveness.

(1) Openness and Pluralism

American culture has been known to be an open one in the world. Because of the openness of American culture, foreign students can enjoy relatively more freedom, particularly spiritual freedom in the course of their studying in the U.S. American culture has also been known as a plural culture as the U.S. has been described as a nation of nations, a people of peoples. More than any other country it has brought together people from diverse cultural backgrounds and joined them to form a single society. Due to the openness of American culture, diversified cultures have been allowed to co-exist in the U.S. society and the cultural pluralism has been achieved in the U.S. society. Therefore, foreign students in the U.S. have had greater opportunities for meeting, exchanging and understanding as much varied cultures as possible.

\section{(2) Pervasiveness}

Since the 1980s, with the rapid expansion of the U.S. economy mainly in the form of transnational corporations around the whole world, the American popular culture marked by Hollywood films, Broadway plays, Black Jazz, fast food and so on has been successfully spreading to every part of the world and become globally pervasive, thus creating much cultural attraction to foreign students. The pervasiveness of the American culture can be shown by the following two facts. A study report made by UNESCO in 1993 claimed that the export volume of the American TV programs had been eight times as much as that of the British ones, the second largest exporter in the world. Another fact has been the U.S. absolute domination in the world movie market since the 1990s. Although the annual production of the U.S. films has accounted for some 6 to 7 percent of the world total in the 1990s, the U.S. films have taken up as much as half the time on the world screen .

The above-mentioned objective factors involving the American higher education, science, technology, economy and its culture have determined to a large extent the top status of the American educational market for foreign students in the world. However, great efforts made by the U.S. society in recruiting foreign students have also been helpful for the U.S. dominant status of the educational market for foreign students in the world since the 1980s.

\subsection{Persistent Efforts Made from the Whole U.S Society}

\subsubsection{Efforts from American Higher Educational Institutions}

American higher educational institutions have been actively engaged in recruiting foreign students through Internet since the 1980s and almost all accredited American higher educational institutions have established their own websites containing much useful information, such as detailed enrollment requirements, tuitions and related fees, curriculum layout, forms of financial aid, and so on. In addition, some U.S. higher educational institutions have even granted foreign students to apply on-line for the application for admission. In addition to the institutional websites, two special websites in the U.S. known as Apply To College and EMBARK have also been engaged in the application for admission. The web-based information platform has not only increased foreign students' opportunities to get familiar with the state of the American higher educational institutions but also helped save foreign students a lot of money and time on looking for proper schools for studying abroad, thus providing much convenience to foreign students dreaming of pursuing higher learning abroad.

\subsubsection{Efforts from U.S. Federal Government}

Three U.S. Federal Departments-State, Commence and Education have had programs or organizations devoted to encouraging foreign students to study in the U.S. colleges and universities since the 1980s.

In the Department of State, the Educational Information and Resources Branch's primary goal has been to promote the American higher education abroad through a global network of the U.S. educational information centers throughout the world. The role of the Educational Information and Resources Branch has been primarily to provide the American educational centers abroad with reference materials about American higher education, including institutional profiles, information about application, procedures, financial assistance options and standardized test requirements, etc.

The primary aid to American higher education in the American Commerce Department has come from the Commercial Service. Within the Commercial Service, about a dozen American domestic trade specialists with a special interest in the higher education industry have constituted an education team whose work has been to upgrade the knowledge and skills related to the "higher education industry" and to identify potential "clients"---foreign students.

Within the Department of Education, the United States Network for Education Information has essentially been a 
website, providing general information about American higher educational system to foreigners. It has also contained links to other American websites containing information about the American higher education.

\subsubsection{Efforts from American Business and Foundations}

Apart from the efforts made by the American higher education and the American Federal government, the support from the American business and various kinds of foundations have also been helpful for the dominant status of the educational market for foreign students in the U.S. since the 1980s. Some large corporations in the U.S. have directly set up scholarship programs for foreign students in their own names since the 1980s. For example, the U.S. AT\&T Company has annually awarded 36 foreign students from China and India in the name of "AT\&T scholarship for Talents", each getting as much as \$5,000. Likewise, a survey conducted by the American Foundation Center in 2000 showed that between 1990 and 1996 funding by a group of 800 foundations for international exchange programs in the American higher education rose from $\$ 89.2$ million to $\$ 116.3$ million which can be viewed as a robust support for the educational market for foreign students in the U.S.

\subsection{Changes in the World Economic Situation}

Since the 1980s, especially since the end of Cold War, the globalization of the world economy has been quickening its pace in the fact that a highly considerable number of cross-national economic cooperation organizations have emerged on the world stage one after another, among which the European Community, the North American Free Trade Zone and the Asia-Pacific Economic Cooperation organizations being the most influential three in the world. Entering into the 1990s, the economic development of a nation has been increasingly dependent on its involvement in the global market for world economy and trade. As a result, the trend toward globalization of world economy and trade has compelled every nation in the world, especially the developing nations, to cultivate the increasing number of international talents who have had both a thorough understanding of the international market of economy and trade and at the same time have been quite familiar with diversified cultures to be competent in participating in cross-cultural economic management and production. In view of the U.S. global dominance in the field of economy, science, technology and even culture, the U.S. has naturally been the most attractive nation to foreign students around the world.

\subsection{Changes in the World Political Situation}

Since the 1980s, especially since the end of the Cold War, great political changes have also taken place in the world, especially in the former Soviet Union and the Eastern European countries. The violent political changes in these nations have definitely sent many foreign students to the U.S.

Before the end of the Cold War, the former Soviet Union, like the Western developed nations, also owned a large educational market for foreign students. In 1990, the Soviet Union had on record the highest number of 126,500 foreign students from 135 countries and its annual enrollments of foreign students began to decrease sharply ever since. In 1991, all together 102, 800 foreign students were attracted to the Soviet Union. In 1992 and 1993, Russia, the successor to the former Soviet Union, received only 42,100 and 26,000 foreign students. The Eastern European countries also used to host quite a number of foreign students from the developing countries. However, due to the rapid political changes in these countries, quite a number of foreign students from the developing countries and even numerous Eastern European students have flowed into the U.S. for study.

Likewise, with the establishment of Sino-U.S. diplomatic relationship, over two-thirds of all the Chinese students who studied abroad have chosen the U.S. as their most popular destination. Since the early 1990s, China has been leading the growth of foreign student enrollment as the top sending country.

\section{Conclusion}

After the above analysis of the causes for the US dominant status in the world educational market, it is not difficult for us to conclude that it is the U.S. world-leading comprehensive national strength that has established U.S status in the globe educational market for foreign students since the 1980s. In other words, the top status of the American educational market has been determined to a large extent by the U.S. superpower status in the world. As long as the U.S maintains its superpower position in the world, its educational market for foreign students will still top the world.

\section{References}

Alice Chandler. (1989). Obligation or opportunity: foreign student policy in six major receiving countries. Institute of International Education, New York. 11-31.

American Council on Education. (1995). International challenges to American colleges and universities.11-31.

Eugene Provenzo. (1985). An introduction to education in American society. London, U.K: Charles E. Merrill 
Publishing Company. 30-45.

Iriye Akira. (1997). Cultural internationalism and world order. Baltimore, USA: The Johns Hopkins University Press.1-11.

Jane Knight. (1995). Perspective on the internationalization of higher education, Studies in international education. Institute of International Education, New York. 121-153. [Online] Available: http://www.opendoors.iienetwork.org/

Qu Hengchang. (2001). World higher education yesterday and today. Studies on comparative education. 60-64.

Zhou Jizhong. (1993). International Science and Technology and Economic Cooperation. Beijing: China Science Publishing House. 285-286.

Zhu Bing. (2001). American science and technology in current times. Beijing: China Science Publishing House. 211-222.

\section{Notes}

Note 1. The other four major English-speaking countries refer to the U.K., Canada, Australia and New Zealand. The document is obtained from the U.S. Department of Education website $<$ http://www.ed.gov/ $>$

Table 1.Foreign Students Admitted by Top Host Countries (from 1980-1995)

\begin{tabular}{|l|l|l|l|l|l|}
\hline \multicolumn{1}{r|}{ Year } & 1980 & 1985 & 1990 & 1995 & $\begin{array}{l}\text { Increase rate } \\
(80-95)\end{array}$ \\
\hline Country & & & & & 4.82 \\
\hline Canstralia & 8777 & 16075 & 28993 & 42415 & 1.11 \\
\hline France & 28433 & 29496 & 35187 & 31435 & 1.12 \\
\hline Germany & 116703 & 131979 & 136015 & 130431 & 2.54 \\
\hline Japan & 61841 & 79354 & 107075 & 159894 & 3.52 \\
\hline U.K & 8543 & 12442 & 23816 & 52511 & 6.09 \\
\hline U.S & 56003 & 53694 & 80183 & 197188 & 1.44 \\
\hline
\end{tabular}

Data Source: Cited from Qu Hengchang, World Higher Education Yesterday and Today.

Table 2. Internationally Comparative Study on R\&D Funds (by Year) Unit: billion dollars

\begin{tabular}{|l|l|l|l|l|l|}
\hline Indicator & U.S. & Japan & Germany & France & U.K \\
\hline 1985 R\&D & 114.3 & 35.4 & 18.7 & 13.5 & 11.8 \\
\hline 1993 R\&D & 166.8 & 74.4 & 47.4 & 32.3 & 24.1 \\
\hline 1996 R\&D & 184.6 & 153.1 & 53.6 & 35.6 & 22.6 \\
\hline
\end{tabular}

Date Source: Cited from Zhou Jizhong, International Science and Technology and Economic Cooperation. 